\title{
EDITORIAL
}

\section{RETOMANDO LA SECCIÓN DEBATES EN CHUNGARA}

\author{
RE-INSTANTING THE DEBATE FORUM IN CHUNGARA
}

\author{
Dante Angelo ${ }^{1,3}$ y Daniel H. Sandweiss D $^{2,3}$
}

Este número parte con un sencillo pero significativo homenaje al colega Donald Jackson, quien nos dejó hace poco más de un año. Su presencia se ve reflejada en apreciaciones de estudiantes, colegas y amigos que comparten la pasión de Donald: la arqueología. En cierta forma, uno podría decir que el trabajo de Donald quedó inconcluso, si se piensa en lo que él tenía que aportar a la disciplina, pero quizás es conveniente pensar que esta inconclusividad es el motor que alimenta a quienes aprendieron de él y compartieron su interés por una arqueología desafiante y ambiciosa. Esperamos que este homenaje acerque a Donald a esa audiencia que no tuvo la oportunidad de conocerlo y le permita apreciar su aporte como un científico comprometido con su disciplina, con sus colegas y con sus amigos.

Tenemos también el gusto de incorporar en este número la entrevista que Cristián Simonetti y Diana Espírito Santo (ambos de la Universidad Católica de Chile) hicieron a Tim Ingold, uno de los antropólogos más reconocidos en las últimas décadas. El trabajo de Ingold trasciende la antropología para internarse en temáticas de arquitectura, arte, materialidad -más recientemente, como lo anuncia aquí-, y en la educación. La contribución de los colegas Simonetti y Espírito Santo es acertada y nos acerca a un Tim Ingold que no duda en exhibir sus expectativas o desagrados respecto de la teoría o la práctica antropológica.

En la línea de Arqueología y Patrimonio de la revista se presentan trabajos que abordan diversas temáticas y cubren, en términos amplios, los distintos períodos cronológicos de ocupación de los territorios de la costa del Pacífico (Castro et al., sobre el Arcaico y Muñoz y Gordillo, en relación con el período Medio en los valles de Azapa y Caplina) y el valle del Maipo (Stehberg, quien aborda el tema
This issue pays homage to our colleague Donald Jackson, who recently passed away. His presence is reflected in the words of students and friends who share Donald's passion: archaeology. One could say that Donald's untimely departure left his work incomplete, given that he had much more to offer the discipline. However, it might be better to think that it is just this inconclusiveness that moves those who learned from him and shared his interest in a challenging and ambitious archaeology. We hope that this homage will bring those who did not know Donald closer to his work and help them to appreciate his contributions and commitment.

We also are pleased to present Christian Simonetti and Diana Espirito Santo's (Universidad Católica de Chile) interview of Tim Ingold, when he visited Chile. Tim Ingold is one of the most influential anthropologists of recent decades and his work transcends anthropology to include fields such as architecture and art, and themes such as materiality and, more recently - as he announces here-education. The contribution by Simonetti and Espirito Santo introduces an Ingold who does not hesitate to show his theoretical expectations and dislikes regarding the practice of anthropology.

As part of the Archaeology and Heritage section of Chungara, this issue includes a thematically and chronologically wide array of works. The occupation of the coastal territories of the Pacific Ocean is discussed for at least two distint chronological periods: by Castro and colleagues, regarding the Archaic Period on the coast of Antofagasta, and by Muñoz and Gordillo, regarding the Middle Horizon in the Azapa and Caplina coastal valleys; moving

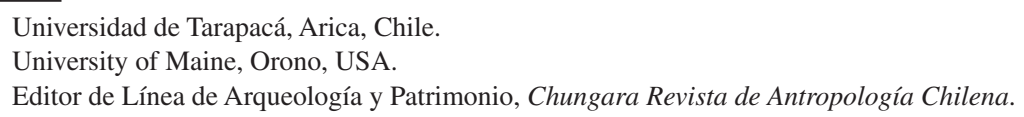


de la ocupación de territorios septentrionales por el estado inca); Gili y colegas abordan el estudio de semillas de cebil y sus variedades Anadenathera colubrina var. cebil y Acacia visco desde una mirada interdisciplinaria arqueobotánica y química, para la correcta identificación de ambas especies en contextos arqueológicos del norte de Chile. El artículo de Tantaleán y Zapata se enfoca en el sitio arqueológico Chaupisawakasi a partir del cual los autores abordan el fenómeno de expansión de la sociedad Pukara durante el Formativo Superior y sus implicancias politico-regionales en torno a la formación de un Estado teocrático en los Andes Centrales.

En la línea de Antropología e Historia, por una feliz coincidencia, un par de trabajos presentan temáticas que han estado vigentes en las discusiones antropológicas de los últimos tiempos: el giro ontológico en antropología (De Munter, y su trabajo entre familias Aymaras, y Rojas, sobre rituales Mapuche); esto, de cierta forma, complementa la discusión presente en la entrevista de Simonetti y Espírito Santo. Aunque parece desviarse ligeramente del tema, Carlos Piñones y colegas nos ofrecen una mirada de la semiótica religiosa Aymara-pentecostal que, quizás, algunos estarían de acuerdo en que este tema podría ser considerado como parte de miradas ontológicas en transformación. Cassigoli, por su parte, revisita el importante trabajo de Michel de Certeau a partir de su contraposición con teóricos como Wittgenstein y otros, acerca de aspectos relacionados a memoria, historicidad y cotidianeidad, temas a los que la autora ha contribuido durante su carrera.

Siguiendo el objetivo principal de la Revista que es el de promover e impulsar el conocimiento arqueológico, antropológico e histórico, Chungara retoma la sección de Debate que busca promover el intercambio de ideas entre colegas e investigadores. Agradecemos a Tom Dillehay por su buena predisposición y aceptar la propuesta de la Revista para servir como el "conejillo de indias" para una de las secciones que Chungara busca reimpulsar en futuros números. Tom Dillehay es uno de los arqueólogos norteamericanos más conocidos en el ámbito académico latinoamericano no solo por las contribuciones científicas realizadas, las cuales incluyen trabajos en torno a la historia prehispánica de América del Sur, sino también por su familiaridad con Chile y Latinoamérica. Podría decirse que Chile es su segunda casa -al igual que Chungara, further south, Stebergh's work deals with the Inca occupation of the Maipo valley, while Gili and colleagues, working with archaeological contexts of northern Chile, present an interdisciplinary study of the cebil seeds and its varieties, Anadenanthera colubrine var. cebil and Acacia visco, exploring chemical and archaeo-bothanical methods to accurately identify both species. Tantaleán and Zapata's article focuses on the archaeological site of Chaupisawakasi, drawing on excavations of the site they scrutinize the expansion of the Pukara society, during the Upper Formative; the authors assess the regional and political implications in the configuration of a theocratic State in the Central Andes.

By happy coincidence, our Anthropology and History section presents several articles (De Munter's work with Aymara families and Rojas' approach to Mapuche rituality) explicitly dealing with a theme that recently has gained a lot of attention: the ontological turn in anthropology. This nicely complements the discussion in Simonetti and Espirito Santo's interview. Although it would seem to be a slight detour from the topic, Piñones'and colleagues' work on the semiotics of Aymara-Pentecostal religiosity, seen as ontological transformations, could also be included in this set of contributions. This section closes with the paper by Cassigoli, who revisits the work of Michel de Certeau by contraposing his ideas about memory, historicity and continuity to those of theorists like Wittgenstein and others.

Because the main goal of Chungara is to foster anthropological, archaeological and historical knowledge, we have the pleasure of re-instating the section of Debate, which seeks to promote the exchange of thoughts among colleagues and researchers. Here, we want to thank Tom Dillehay for his willingness to accept Chungara's proposal to be part of this experiment, an experiment that we hope to continue in future issues. Tom Dillehay is one of the best known US archaeologists in the Latin American scene, not only because of his contributions, which range from early settlement of the Americas to historical periods, but also 
a la cual ha apoyado constantemente-, por esto, apreciamos su contribución.

El ensayo que Tom Dillehay nos presenta y que nos permite retomar esta sección en Chungara emana de una monografía editada y liderada por él, titulada The Teleoscopic Polity: Andean Patriarchy and Materialty (Dillehay 2014). Consideramos que la presentación de esta síntesis en Chungara Revista Chilena de Antropología, contribuye a la difusión de su propuesta ante la audiencia local y nacional -quizás directa e indirectamente más relacionada con esta temática y problemática-y aquella de más allá de las fronteras nacionales, que esperamos pueda interesarse y profundizar la discusión que aquí se inicia. Por supuesto, debido al reducido espacio del formato no es posible condensar en su totalidad el trabajo que Dillehay y colegas desarrollan en dicho libro en el acotado ensayo que aquí se presenta; no obstante, permite conocer algunos de sus principales argumentos, y otros adicionales, en donde un grupo de colegas relacionados al tema vierten su opinión.

El tema elegido por Tom Dillehay es parte de un debate histórico que busca entender los complejos procesos históricos en torno a la sociedad Mapuche; habiéndose iniciado hace mucho tiempo ya, sigue presente en el corazón de la discusión académica. La intrusión en el debate por parte de Dillehay, antropólogo de formación y quizás más conocido por su trabajo arqueológico, tanto en la región sur de Chile como en las costas del Perú, no es fortuita. Ya antes el autor exploró, desde una perspectiva histórica $-\mathrm{y}$ etnohistórica-, aspectos relacionados a la política Mapuche (ver por ejemplo, Dillehay 1986, 1990), los cuales son la base de su trabajo Monuments, Empires, and Resistance: The Araucanian polity and ritual narratives 1 (Dillehay 2007; ver también Dillehay y Zabala 2013; Zabala et al. 2010, y otros).

El ensayo que aquí se presenta no solo es un tema de interés para arqueólogos, historiadores, antropólogos, cientistas políticos o estudiosos del derecho, sino también de una gama de profesionales y público que ha sido testigo o partícipe de los procesos a los que aquí se hacen referencia. Lejos de ser una temática aislada, o de interés restringido a demarcaciones fronterizas, su abordaje permite la reflexión de aspectos teórico-conceptuales en torno a contextos sociopolíticos que están vivamente presentes en diversas regiones de nuestro continente y más allá. Las propuestas del autor son consideradas y comentadas por un grupo de estudiosos que fue seleccionado por Chungara, en consideración de because of his familiarity with Chile and other South American countries. It could even be said that Chile and Chungara (to which he has constantly contributed) are his second home; for that, we are thankful.

Dillehay's essay, with which we reopen the Debate section, is based on his previous book titled The Teleoscopic Polity: Andean Patriarchy and Materialty (Dillehay [ed.] 2014). We believe that presenting it here will contribute to expanding access to Dillehay's contributions and thoughts by a local and national audience and, therefore, to further a debate that only begins here. We are aware that space constraints do not allow Dillehay and his colleagues to adequately present all the ideas covered in the aforementioned volume; however, the essay included in this issue will provide the audience of Chungara with the main arguments along with the reactions of a select group of colleagues who specialize in the subject.

Tom Dillehay's work is part of a long-standing debate about the complexity of the historical processes of Mapuche society. Dillehay's entry into this debate is not accidental; although he is better known for his contributions to archaeology, as an anthropologist Dillehay has previously explored different aspects of Mapuche politics from a historical perspective (Dillehay 1986, 1990). He elaborated on this work in Monuments, empires, and resistance: The Araucanian polity and ritual narratives 1 (Dillehay 2007; see also Dillehay and Zabala 2013, Zabala et al. 2010 among others).

The work that Dillehay presents now is not only of interest to archaeologists, historians, anthropologists and other scholars from disciplines such as political science or law but also to a wide range of other academics and to a much broader audience that has been a witness or a part of the processes referred to here. Addressing this issue allows reflection on the historical and socio-political contexts that, far from being over, are part of the political struggle for indigenous peoples throughout the Americas and beyond. Here, Dillehay's thoughts are discussed by a group of scholars who specialize in this subject and who 
su trayectoria como investigadores del tema y sus contribuciones a la discusión, entre ellos André Menard, Rolf Foerster, José A. Isla, José Quidel Lincoleo, Rosamel Millaman Reinao, Julio Esteban Vezub, José Bengoa y Cristián Perucci González.

Algunos de los puntos que se abordan en la discusión están relacionados a problemas teóricos y metodológicos, como es el de la conceptualización e interpretación de eventos específicos que está en el corazón de la discusión. Podría decirse que, en términos metodológicos, el trabajo con fuentes históricas ha dejado de ser exclusividad de historiadores. Las contribuciones que el material documental, archivos y otros escritos otorgan a las investigaciones arqueológicas y antropológicas han probado ser altamente fructíferas; así, son muchos y variados los ejemplos de trabajos de investigación en los que las fronteras metodológicas se amplían para proveer nuevos e interesantes resultados, algunos de estos se reflejan en la producción de nuevas preguntas y cuestionamientos que amplían nuestras conceptualizaciones teóricas.

Como se muestra en el diálogo de nuestros invitados, las diferencias disciplinarias son claramente observables, con una demanda mayor de datos por una parte y por otra con un planteamiento crítico más atrevido. El intento que Chungara realiza en esta ocasión, retomando esta sección de debate, tiene por objeto precisamente el trascender estas fronteras disciplinarias, con el fin de promover dinámicas de interpretación que provengan del intercambio dialogal entre disciplinas. Creemos que promover el debate es crucial para lograr un conocimiento cada vez más integrado.

Finalmente, cerrando este número, Calogero Santoro nos ofrece una reseña del libro de César Méndez, uno de los más prolíficos académicos de esta generación, en torno a los primeros pobladores del actual territorio chileno, y del continente americano, hace 13.000 años. Recientemente, datos provenientes de nuevas investigaciones han abierto puertas insospechadas acerca de la profundidad cronológica y formas de vida de los primeros pobladores de esta parte del continente. La experiencia de Calogero, uno de los fundadores de Chungara y activo investigador del poblamiento americano, remarca la importancia de este trabajo y su reseña permitirá al lector interesado un acercamiento más agudo a esta apasionante temática. Esperamos e invitamos a los colegas a seguir aportando con sus trabajos. kindly accepted our invitation to participate. We thank André Menard, Rolf Foerster, José A. Isla, José Quidel Lincoleo, Rosamel Millaman Reinao, Julio Esteban Vezub, José Bengoa and Cristián Perucci González for their contributions.

Some of the aspects analyzed by the authors relate to theoretical and methodological problems such as the conceptualization and interpretation of specific events. Methodologically, the work with historic sources is no longer the exclusive domain of historians. The use of historic documents and archives has proven extremely fruitful for archaeological and anthropological research; thus, there are many examples in which the methodological frontiers have been widened to provide new and intriguing results. Some of these results have been instrumental in the creation of new research questions, broadening our own theoretical views.

The exchange of thoughts in this dialogue shows some clear disciplinary differences, with demands for more historical information, on the one hand, and for more critical stances, on the other. What Chungara seeks with this Debate section is precisely to transcend those disciplinary boundaries through new dialogic dynamics between disciplines. We are convinced that promoting this debate is crucial to achieving a more integrated knowledge of history.

Finally, in closing, Calogero Santoro, one of the founders of Chungara and a renowned researcher of the early settlement of the Americas, provides a review of César Méndez's latest book Los Primeros Andinos. Tecnología Lítica de los Habitantes del Centro de Chile Hace 13.000 Años. Méndez, one of the most prolific scholars of his generation, tackles the issues of technology among the first settlers of this side of the continent. Calogero's review emphasizes the importance of this book and, we hope, will provide some clear guidance to the reader interested on this subject. We invite our colleagues to continue supporting Chungara's goals by sending us their contributions to consider. 


\section{Referencias Citadas}

Dillehay, T.D. 1986. Cuel: observaciones y comentarios sobre los Túmulos en la cultura Mapuche. Chungara 16-17:181-193.

Dillehay, T.D. 1990. Mapuche ceremonial landscape, social recruitment and resource rights. World Archaeology 22:223-241.

Dillehay, T. 2007. Monuments, Empires, and Resistance. The Araucanian Polity and Ritual Narratives. Cambridge University Press, Cambridge.

Dillehay, T.D. (ed.) 2014. The Teleoscopic Polity: Andean Patriarchy and Materiality. Springer Science \& Business Media, New York.

\section{Nota}

1 Este trabajo fue posteriormente traducido al español y editado conjuntamente por la Universidad Católica del Norte y la Universidad de Vanderbilt, bajo el título de: Monumentos, imperios y resistencia en los Andes. El sistema de gobierno mapuche y las narrativas rituales (Dillehay 2011).
Dillehay, T.D. y J.M. Zavala 2013. Compromised landscapes: The proto-panoptic politics of colonial Araucanian and Spanish Parlamentos. Colonial Latin American Review 22:319-343

Zavala Cepeda, J.M. y T.D. Dillehay 2010. El "Estado de Arauco" frente a la conquista española: Estructuración sociopolítica y ritual de los Araucano-Mapuches en los valles Nahuelbutanos durante los siglos XVI y XVII. Chungara Revista de Antropología Chilena 42:433-450.

\section{Note}

1 This work was translated into Spanish and published jointly by the Universidad Católica del Norte and Vanderbilt University as: Monumentos, imperios y resistencia en los Andes. El sistema de gobierno mapuche y las narrativas rituales (Dillehay 2011). 
